\title{
Hypertension and diabetes treatment affordability and government expenditures following changes in patient cost sharing in the "Farmácia popular" program in Brazil: an interrupted time series study
}

\author{
Isabel Cristina Martins Emmerick ${ }^{1,2^{*}}$ (D) Mônica Rodrigues Campos ${ }^{3}$, Rondineli Mendes da Silva ${ }^{4}$,
} Luisa Arueira Chaves ${ }^{5}$, Andréa Dâmaso Bertoldi ${ }^{6}$, Dennis Ross-Degnan ${ }^{7}$ and Vera Lucia Luiza ${ }^{4}$

\begin{abstract}
Background: Increasing medicines availability and affordability is a key goal of Brazilian health policies. "Farmácia Popular" (FP) Program is one of the government's key strategies to achieve this goal. Under FP, antihypertension (HTN) and antiglycemic (DM) medicines have been provided at subsidized prices in private retail settings since 2006, and free of charge since 2011. We aim to assess the impact of sequential changes in FP benefits on patient affordability and government expenditures for HTN and DM treatment under the FP, and examine their implications for public financing mechanisms and program sustainability.

Methods: Longitudinal, retrospective study using interrupted time series to analyze: HTN and DM treatment coverage; total and per capita expenditure; percentage paid by $\mathrm{MoH}$; and patient cost sharing. Analyzes were conducted in the dispensing database of the FP program (from 2006 to 2012).

Results: FP has increased its coverage over time; by December 2012 FP covered on average 13\% of DM and 11.5\% of HTN utilization, a growth of over 600 and 1500\%, respectively. The overall cost per treatment to the MoH declined from $\mathrm{R} \$ 36.43$ ( $\mathrm{R} \$=$ reais, the Brazilian currency) to 18.74 for $\mathrm{HTN}$ and from $\mathrm{R} \$ 33.07$ to $\mathrm{R} \$ 15.05$ for DM over the period analyzed, representing a reduction in per capita cost greater than $50 \%$. The amount paid by patients for the medicines covered increased over time until 2011, but then declined to zero. We estimate that to treat all patients in need for HTN and DM in 2012 under FP, the Government would need to expend 97\% of the total medicines budget.

Conclusions: FP rapidly increased its coverage in terms of both program reach and proportion of cost subsidized during the period analyzed. Costs of individual HTN and DM treatments in FP were reduced after 2011 for both patients (free) and government (better negotiated prices). However, overall FP expenditures by MoH increased due to markedly increased utilization. The FP is sustainable as a complementary policy but cannot feasibly substitute for the distribution of medicines by the SUS.
\end{abstract}

Keywords: Non-communicable diseases, Affordability, Hypertension, Diabetes, Government expenditure, Medicines

\footnotetext{
* Correspondence: emmerick.isabel@gmail.com

'Division of Thoracic Surgery - Department of Surgery, University of

Massachusetts Medical School, 67 Belmont street, Worcester, MA 01605, USA

${ }^{2}$ Pharmaceutical Policy Research Fellowship, Department of Population

Medicine, Harvard Medical School \& Harvard Pilgrim Health Care Institute,

Landmark Center, 401 Park Drive Suite 401, Boston, MA 02215, USA

Full list of author information is available at the end of the article
}

(c) The Author(s). 2020 Open Access This article is distributed under the terms of the Creative Commons Attribution 4.0 International License (http://creativecommons.org/licenses/by/4.0/), which permits unrestricted use, distribution, and reproduction in any medium, provided you give appropriate credit to the original author(s) and the source, provide a link to the Creative Commons license, and indicate if changes were made. The Creative Commons Public Domain Dedication waiver (http://creativecommons.org/publicdomain/zero/1.0/) applies to the data made available in this article, unless otherwise stated. 


\section{Background}

Treatment of hypertension (HTN) and diabetes (DM) is considered a health policy priority in Brazil, with particular attention paid to reducing preventable hospital admissions. Recent reductions have been associated with the expansion of the primary care, which facilitates early detection, and treatment of HTN and DM [1].

The main characteristics of the principal medicines provision mechanisms in place in Brazil are summarized in Table 4 in Appendix. Access to medicines and health care is universal [2] and there is no barrier to obtaining medicines from different sources. Patients can obtain medicines free at public health facilities, through "Farmácia Popular" (FP), or by paying out-of-pocket at private retail pharmacies simultaneously.

The "Farmácia Popular" (FP) is a medicines provision mechanism first implemented in 2004. In its first phase, medicines were provided in public health care facilities at a flat price, corresponding to the price obtained by the government in open bidding, plus administrative costs. This program was named "Farmacia Popular Rede Própria". In 2006 the program, then named "Aqui tem Farmacia Popular - AFP" ("Farmácia Popular" is available here- AFP-I), was expanded to private pharmacies contracted with the Ministry of Health. Medicines were charged in a coinsurance model, with the government paying $90 \%$ of a reference price and patients paying $10 \%$ of the selling price (which might be higher than the reference price). To improve accountability of pharmacies, a new administrative system was implemented in 2009 (AFP-II) that provided information on each patient claim.

Subsequently, antihypertensive, antidiabetic (since 2011), and antiasthma medicines (since 2012) began to be dispensed with zero copayment from patients in both government-owned facilities $(n=558)$ [3] and contracted private pharmacies $(n=25,150$, covering $63.4 \%$ of the 5570 municipalities [3]). This change was named as "Saúde não tem preço - SNP" (Health has no price). Except for metformin $500 \mathrm{mg}$ (extended release), all medicines covered in FP for these three conditions that are included in RENAME (the National Essential Medicines List) were provided free-of-charge in SUS. The SNP makes treatment affordable for patients, but this benefit might be unsustainable in the long term, especially in a country that has other forms of provision.

Currently, the FP program continues to provide free medications for treatment of asthma, diabetes and hypertension, and co-finances drugs for treatment of dyslipidemia, osteoporosis, rhinitis, Parkinson's and glaucoma, as well as contraceptives and geriatric diapers, totaling approximately $\mathrm{R} \$ 2.9$ billion in 2017 [4].

FP is widely seen as a successful program that has expanded coverage in both the number of individuals treated for DM and HTN and in the number of dispensings per person [5-7]. However, a number of studies have cautioned about the program's high expenditures $[8,9]$. On the other hand, the FP program has been associated with reduced rates of hospital admissions and mortality per 100,000 inhabitants [4]. In parallel with increased government expenditures, families' health expenditures have also been increasing [10], especially for medicines. It is thus relevant to examine the impact of FP on both government expenditures and medicines affordability.

This paper aims to analyze the impact of the sequential Farmácia Popular interventions on patient affordability and government expenditures for HTN and DM treatment under the FP program, and consider their implications for public financing mechanisms and program sustainability.

\section{Methods}

This is a longitudinal, retrospective study using interrupted time series (ITS) to examine out-of-pocket payments and $\mathrm{MoH}$ expenditures for HTN and DM treatment. The main outcomes addressed are rates of HTN and DM treatment coverage, number of individuals in FP, total expenditures, percentages paid by $\mathrm{MoH}$, treatment cost per capita and out of pocket payment.

The Brazilian National Ethics Committee, by the National School of Public Health - Fiocruz - Brazil and the WHO ERC, approved the ISAUM-Br project, which is the basis for this paper.

\section{Interventions}

The study interventions are two changes in patient cost sharing in AFP. The April 2009 AFP-II policy involved a reduction in reference prices for most $\mathrm{FP}$ medicines by an average of $24.5 \%$, coupled with administrative changes aiming to improve accountability. In February 2011, the "Saúde não tem preço" (SNP) program was implemented, under which all covered medicines for HTN and DM were dispensed free of charge to patients. FP private pharmacies were reimbursed according to a set of negotiated prices, while in government-owned pharmacies, medicines were fully subsidized. Only FP private pharmacies are addressed in this paper.

\section{Data source and study population}

The FP information system is the first widespread governmental administrative system on medicines dispensing in Brazil. The FP information system in contracted pharmacies is managed by the Unified Health System Informatics Department (DATASUS). Data include patient unique identification number $(\mathrm{CPF})$, price paid, date of purchase, prescribed daily dose and amount procured. CPF allows linking to data on gender and date of birth. In the majority of cases, the buyer corresponds to the 
patient for patients over 18 years old. Other administrative systems cover a small set of medicines (e.g. ARVs, high cost medicines) and are not integrated at national level.

FP program eligibility criteria have remained unchanged during the program: all medicines are sold only if a national ID and a valid prescription are presented. During the study period medicines were dispensed on a monthly basis, although prescriptions were valid for 120 days. Over time, the number of participating private sector pharmacies expanded substantially, especially in some regions [3].

Data are derived from an electronic point-of-sales dispensing program implemented in 2006 in FP retail pharmacies and then integrated online by DATASUS. Available data include patient and pharmacy identifiers, patient age and gender, geographic location of the pharmacy, date of dispensing, name and quantity of medicine dispensed, daily prescribed dose, amount of $\mathrm{MoH}$ reimbursement, and patient copayment.

We use data on dispensing of HTN and DM medicines from October 2006 to December 2012. All patients with at least one dispensing during the study period were included in this analysis. Dispensing data are of good quality and relatively complete, with duplicate cases accounting for less than $0.005 \%$ and individuallevel missing data at less than $0.05 \%$. We excluded encounters with missing data on any outcome variables from all analyses.

Medicines covered by the program include four oral antidiabetic medications (glibenclamide $5 \mathrm{mg}$, and metformin $500 \mathrm{mg}, 850 \mathrm{mg}$, and slow release $500 \mathrm{mg}$ formulations), insulin NPH and regular and six antihypertensive medications (atenolol $25 \mathrm{mg}$, propranolol $40 \mathrm{mg}$, hydrochlorothiazide $25 \mathrm{mg}$, captopril $25 \mathrm{mg}$, enalapril $5 \mathrm{mg}$, and losartan $50 \mathrm{mg}$ ).

\section{Analysis}

We analyzed five study outcomes related to FP program coverage, $\mathrm{MoH}$ expenditures, and affordability, as follows:

1) Monthly number of individuals who received at least one dispensing at AFP pharmacies;

2) Total monthly program expenditure in reais (Brazilian currency), including total $\mathrm{MoH}$ expenditure and total patient payments;

3) Monthly percentage of expenditure paid by the $\mathrm{MoH}$;

4) Monthly expenditure per treatment (per capita), which is the total monthly expenditure divided by the number of individuals in the program; and.

5) Average monthly out-of-pocket payment, which is the average amount paid by patients per treatment.
Annual inflation was a relatively stable 3 to $7 \%$ during the study period. We performed a monthly inflation correction for all financial outcomes [11]. We report all financial outcomes in 2012 inflation-adjusted Brazilian reais; the exchange ratio during the study period was roughly 2 Brazilian reais to 1 US dollar [12].

As an indicator of potential program sustainability, we estimated the level of expenditure that would be needed to fully cover all individuals in Brazil with DM and HTN through the FP program, and calculated the percentage that would represent of total $\mathrm{MoH}$ expenditures on medicines, yearly from 2006 to 2012 .

It has been demonstrated that most people with HTN and DM diagnoses, respectively 95 and $85 \%$, are under pharmacological treatment in Brazil [13]. Thus, it seems fair to use national prevalence to estimate potential FP costs, assuming that all patients were treated through the program. The costs per individual treated in the program consider the average cost per capita per type of disease HTN or DM.

To create this sustainability measure, we first developed two measures estimating annual FP program utilization: a) Number of unique individuals with at least one dispensing within a given year; b) Average number of individuals receiving at least one dispensing per month, averaged across 12 months in a given year (i.e., allowing individuals to repeat across months). We used these to construct annual and monthly estimates of program coverage, where the denominator of each measure is an estimate of the annual prevalence of each disease in Brazil, as a proxy for the number of individuals who should be under treatment [14].

In addition to deriving yearly coverage estimates using FP program data, we also used the FP coverage estimates reported in the following surveys: National Program for Improving Access and Quality of Primary Health Care (Programa Nacional de Melhoria do Acesso e da Qualidade da Atenção Básica - PMAQ-AB) [15], Brazilian Survey on Medicine Access, Utilization and Rational Use of Medicines (Pesquisa Nacional sobre acesso e utilização e promoção do Uso Racional de Medicamentos - PNAUM) [13], Surveillance of risk-factor for chronic diseases through telephone interviews (Vigilância de fatores de risco e proteção para doenças crônicas por inquérito telefônico - VIGITEL [14] and National Health Survey (Pesquisa Nacional de Saúde - PNS) [16].

We did not adjust the monetary values used in this analysis for inflation, since we are comparing the proportions of expenditures in each year, and not actual expenditures themselves.

\section{Statistical methods}

To analyze the impact of Farmácia Popular interventions on affordability and $\mathrm{MoH}$ expenditures, we used 
ITS segmented linear regression models to determine the effect of the FP policy changes on the study outcomes. In estimating effects, ITS models adjust for preexisting trends in the period before the policy change [17]. Segmented linear regression models were constructed using the "prais, corc" command in STATA v12 [18], we analyzed linearity and autocorrelation. ITS considered to be one of the strongest quasi-experimental design to evaluate longitudinal effects of interventions, while segmented regression analysis is a commonly used statistical method for estimating intervention effects in ITS studies [17-22].

Our ITS models included three segments, baseline and one for each of the two program periods, with 29, 22, and 23 monthly observations, respectively. The segmented regression model was specified as follow [17, 20]:

$$
\begin{aligned}
Y_{t}= & \beta_{0}+\beta_{1} * \text { month } \\
& +\beta_{3} * \text { months after } A F P I I_{t}+\beta_{4} * A F P_{t} \\
& +\beta_{5} * \text { months after } S_{t} P_{t}+e_{t}
\end{aligned}
$$

In this model, time (t) is a continuous variable indicating time in months from the start of the observation period; $Y_{t}=$ outcome variable in month $t ; \beta_{0}=$ level at the start of the observation period (intercept); $\beta_{1}=$ baseline trend; month $_{\mathrm{t}}=$ number of months from start of observation; AFPII $_{t}=$ whether month $t$ is after AFPII; $\beta_{2}=$ level change after the AFPII; $\beta_{3}=$ trend change after the AFPII; $\mathrm{SNP}_{\mathrm{t}}=$ whether month $\mathrm{t}$ is after SNP; $\beta_{4}=$ Level change after the SNP; $\beta_{5}=$ trend change after the SNP; $\mathrm{e}_{\mathrm{t}}=$ residual error

The baseline segment was fit with an intercept and a variable estimating trend. We estimate each policy effect by a variable representing the change in level of the outcome immediately after the policy and a second representing the change in trend of the post-policy segment. Patients would experience changes in copayment only when they presented to fill a prescription after the policy change. We thus defined a post-policy implementation period of 2 months for the program to take effect; these periods were excluded in the ITS models so that we could estimate stable post-intervention effects. Additionally, we performed a sensitivity analysis considering the possibility of autocorrelation, assessing the significance of the Durbin-Watson statistic. We found that all outcomes have some level of autocorrelation, we compare the use of "prais" alone, "prais, var rhotype (dw)", and "prais var, corc" [18]. We made an option to use Cochrane-Orcutt procedure "prais var., corc" since it presented the better adjustment. The sensitivity analysis showed that small autocorrelation did not impact the direction, significance of the findings. (Additional file 1).

We retained all parameters in the models regardless of statistical significance. We highlight the results with $p<0.05$. To create single number summaries of policy effects, we calculated estimates of the relative changes in outcomes compared to expected values based on prior trends in April 2010 and February 2012, about 1 year after the two copayment interventions.

\section{Results}

A total of 6,059,643 and 14,447,006 patients received medicines for DM or HTN, respectively, from the FP program. The mean age was 55 years for diabetes and 56 for hypertension patients, with females comprising about $60 \%$ of patients for both diseases. The southeast region represented the majority of patients in the program (Table 1) (Additional file 2).

\section{FP coverage}

Annual coverage of unique patients varied from 3.2 to 16.7\% for DM and 1.6 to $9.7 \%$ for HTN, from 2006 to 2008 , while average monthly coverage varied from 0.9 to $3.7 \%$ for DM and 0.5 to $2.4 \%$ for HTN, respectively. In 2009 and 2010, just after the AFP-II, coverage of unique patients decreased from 17.4 to $12.9 \%$ for DM and 9.8 to $7.1 \%$ for HTN, while average monthly coverage decreased from 3.9 to $3.2 \%$ for DM and 2.4 to $1.9 \%$ for HTN, respectively. After SNP, there was an impressive increase in coverage of unique patients that reached $40.6 \%$ for DM and $32.6 \%$ for HTN by the end of followup, while average monthly coverage reached 13.0 and $11.5 \%$, respectively (Table 1 ).

\section{Number of individuals in FP}

During the baseline period prior to the cost sharing changes, the numbers of individuals covered by the FP program were about 60 and 73 thousand for DM and HTN, respectively, with increasing trends of 12 and 31 thousand additional individuals per month. The AFP-II policy changes were associated with a significant decrease in level and trend, resulting in a relative decrease of over 70\% for DM and 85\% for HTN diseases by April 2010 (Table 2 and Fig. 1). The free medicines policy under SNP was associated with a large expansion in FP participation. The relative increases by February 2012 were 615 and $1507 \%$ for DM and HTN, respectively (Table 2 and Fig. 1).

\section{Total expenditure for DM and HTN}

Total expenditures in the program tracked the changes observed in the number of individuals participating for both DM and HTN, with expenditures increasing steadily prior to April 2009, then experiencing relative declines of 69.9 and $93.3 \%$ by April 2010, 1 year after AFP-II implementation, for DM and HTN, respectively (Table 2 and Fig. 1). The free medicines SNP policy was associated with relative increases in total FP expenditure of 260 and $1812 \%$ for DM and HTN, respectively (Table 2 and Fig. 1). 
Table 1 Participants in "Farmácia Popular is Available Here" program by gender, age, region, and specific coverage. Brazil, 2006 to 2012

\begin{tabular}{|c|c|c|c|c|}
\hline \multirow{2}{*}{$\frac{\text { Variables }}{\text { Age }(n ; \text { mean }(S D)}$} & \multicolumn{2}{|l|}{ Diabetes } & \multicolumn{2}{|l|}{ Hypertension } \\
\hline & & & & \\
\hline Total & $6,059,643$ & $55(15)$ & $14,447,006$ & $56(15)$ \\
\hline \multicolumn{5}{|l|}{ Gender $(n, \%)^{a}$} \\
\hline Female & $3,618,239$ & $59.7 \%$ & $8,666,405$ & $60.0 \%$ \\
\hline Male & $2,425,635$ & $40.0 \%$ & $5,738,940$ & $39.7 \%$ \\
\hline \multicolumn{5}{|l|}{ Region (n, \%) } \\
\hline North & 169,525 & $2.8 \%$ & 470,286 & $3.3 \%$ \\
\hline Northeast & 852,271 & $14.1 \%$ & $2,127,680$ & $14.7 \%$ \\
\hline Southeast & $3,790,268$ & $62.5 \%$ & $8,333,436$ & $57.7 \%$ \\
\hline South & 887,754 & $14.7 \%$ & $2,566,954$ & $17.8 \%$ \\
\hline West-Center & 359,825 & $5.9 \%$ & 948,650 & $6.6 \%$ \\
\hline Coverage $^{1}$ & Number of individuals in the FP & Annual coverage & Number of individuals in the FP & Annual coverage \\
\hline 2006 & 186,286 & $3.2 \%$ & 348,903 & $1.6 \%$ \\
\hline 2007 & 746,279 & $11.2 \%$ & $1,554,871$ & $6.1 \%$ \\
\hline 2008 & $1,251,049$ & $16.7 \%$ & $2,711,688$ & $9.7 \%$ \\
\hline 2009 & $1,300,919$ & $17.4 \%$ & $2,765,155$ & $9.8 \%$ \\
\hline 2010 & $1,041,056$ & $12.9 \%$ & $2,039,368$ & $7.1 \%$ \\
\hline 2011 & $2,682,000$ & $33.2 \%$ & $7,008,960$ & $24.3 \%$ \\
\hline 2012 & $3,755,010$ & $40.6 \%$ & $9,487,841$ & $32.6 \%$ \\
\hline Coverage $^{2}$ & Average individuals per year & Average Monthly coverage & Average individuals per year & Average Monthly coverage \\
\hline 2006 & 52,004 & $0.9 \%$ & 101,945 & $0.5 \%$ \\
\hline 2007 & 150,409 & $2.3 \%$ & 320,338 & $1.2 \%$ \\
\hline 2008 & 280,316 & $3.7 \%$ & 670,006 & $2.4 \%$ \\
\hline 2009 & 290,382 & $3.9 \%$ & 667,345 & $2.4 \%$ \\
\hline 2010 & 254,860 & $3.2 \%$ & 538,718 & $1.9 \%$ \\
\hline 2011 & 715,403 & $8.9 \%$ & $1,722,162$ & $6.0 \%$ \\
\hline 2012 & $1,200,509$ & $13.0 \%$ & $3,330,403$ & $11.5 \%$ \\
\hline
\end{tabular}

Coverage 1. Numerator is the number of individuals with at least one dispensing within the year (individuals do not repeat)

Coverage 2. Numerator is the average monthly individuals in each year (sum of individuals in each month within 1 year divided by 12 months) (the same individual can be count in different months in the same year)

For both coverage indicators the denominator is the estimate prevalence for each disease, which means the number of individuals that should be under treatment. (Brazilian Basic Indicators - http://tabnet.datasus.gov.br/cgi/idb2012/matriz.htm)

${ }^{\mathrm{a}}$ Gender missing Diabetes $0.26 \%$ Hypertension $0.29 \%$

\section{Percentage of expenditures by the Ministry of Health}

Prior to 2009, the $\mathrm{MoH}$ was responsible for 81.3 and $83.4 \%$ of the total expenditures for DM and HTN medications in the program, with a slightly decreasing trend. The cost sharing changes introduced by the AFP-II policy reduced the $\mathrm{MoH}$ share of expenditures at 1 year after the policy change by 14.3 and $16.2 \%$ for DM and HTN, respectively (Table 2 and Fig. 1). Following the SNP free medicines policy, the $\mathrm{MoH}$ started to cover $100 \%$ of medicines expenditures, representing an increase of $69 \%$ for DM and 36\% for HTN by February 2012 (Table 2 and Fig. 1).

\section{Per capita expenditure for DM and HTN treatment}

The cost per treatment per person prior to 2009 varied from $\mathrm{R} \$ 33.1$ to $\mathrm{R} \$ 31.4$ to and $\mathrm{R} \$ 36.4$ to 36.6 for $\mathrm{DM}$ and HTN, respectively, with no significant change following the AFP-II policy change. The free medicines SNP policy was associated with a decrease of around $\mathrm{R} \$ 15$ per treatment, representing a reduction over $37 \%$ by February 2012 for both diseases (Table 2 and Fig. 2).

\section{Out of pocket payment}

In 2006, patients paid an average of $\mathrm{R} \$ 6.3$ for their monthly DM and HTN treatment, respectively. The 


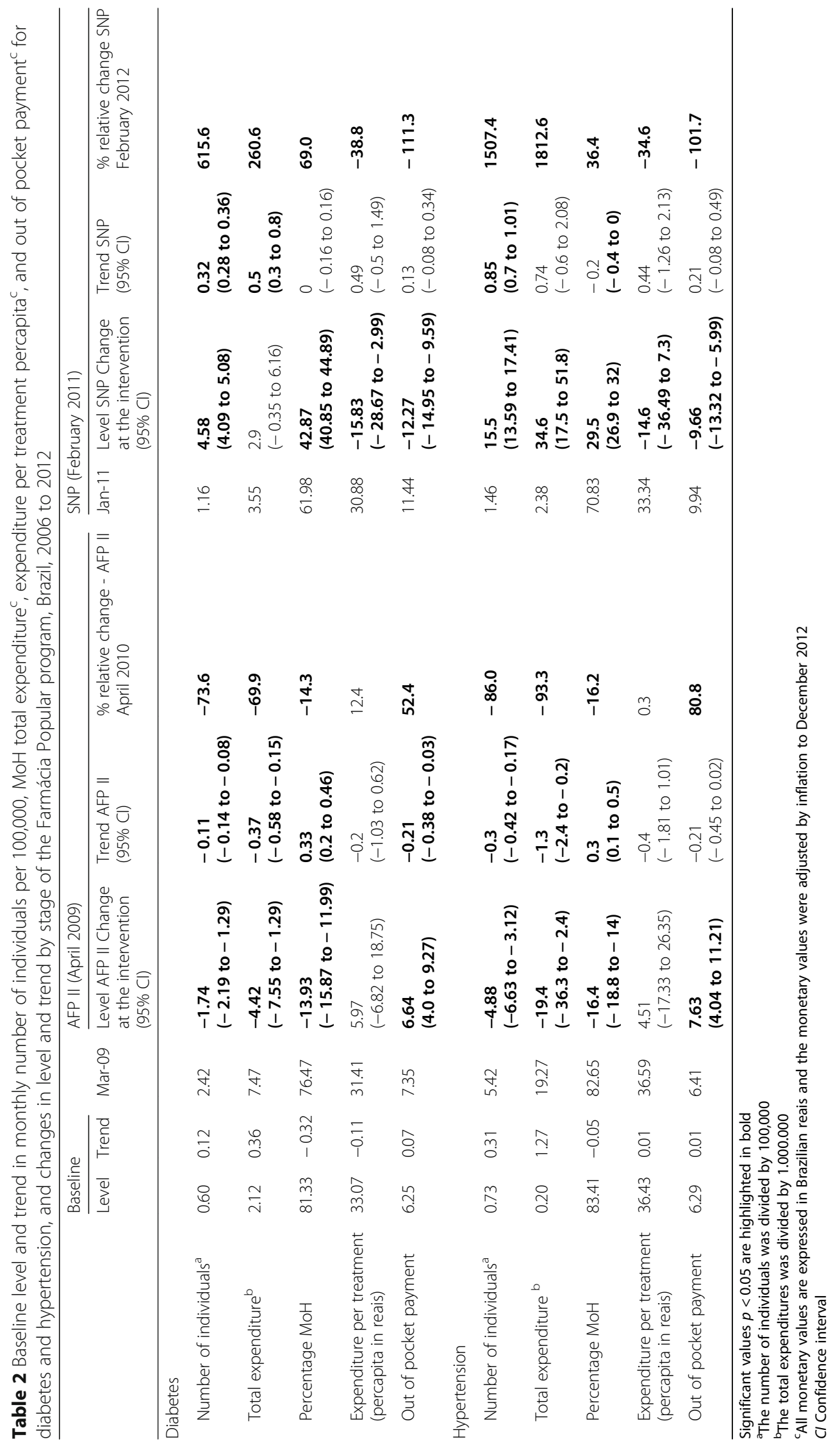




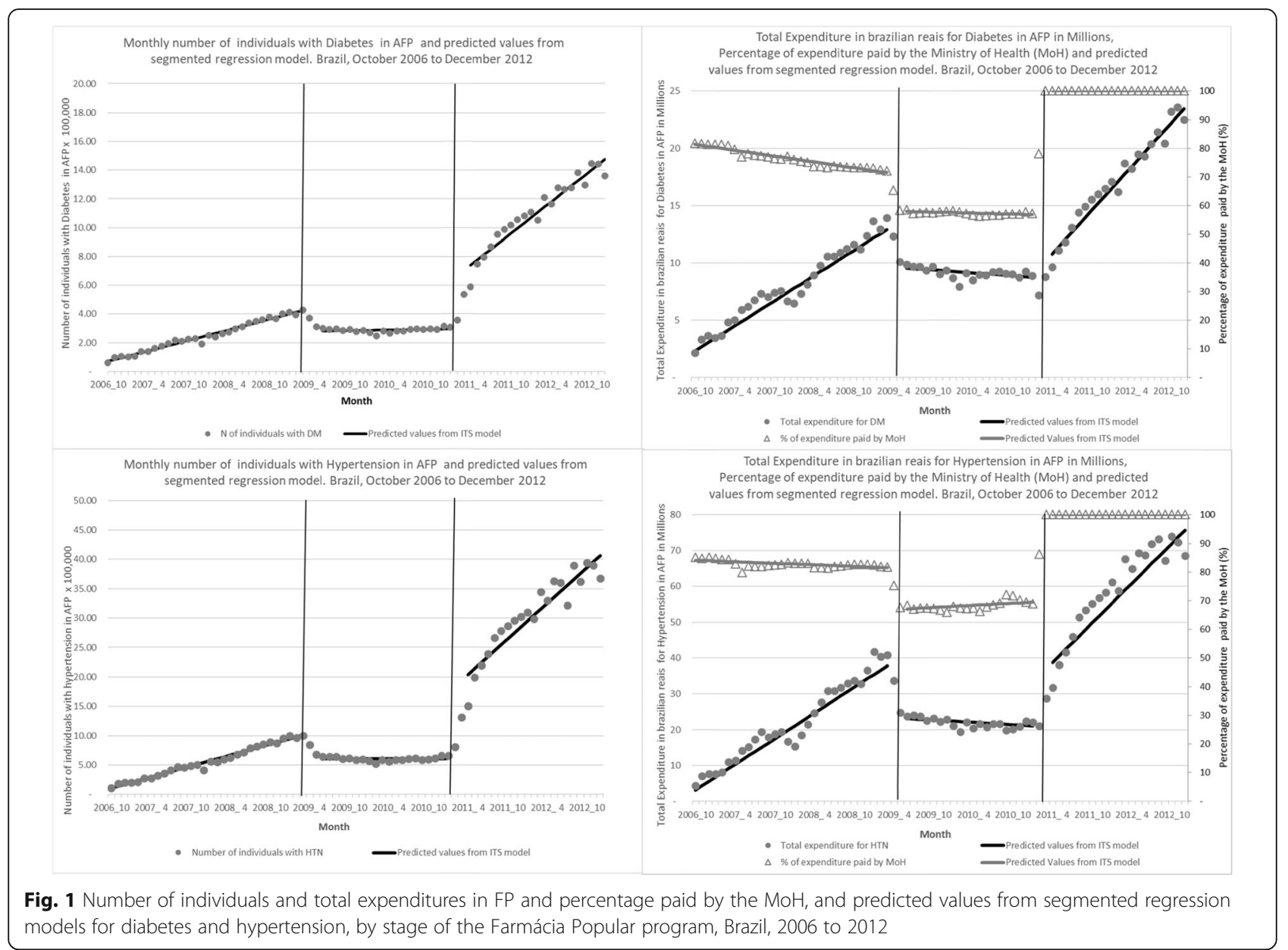

AFP-II policy change was associated with an increase in out of pocket payment of $\mathrm{R} \$ 6.6$ for $\mathrm{DM}$ and $\mathrm{R} \$ 7.6$ for HTN at the time of the intervention, with a relative increase after 1 year of 52.4 and $80 \%$ for DM and HTN, respectively (Table 2 and Fig. 2). The full subsidy introduced by SNP made medicines available free of charge to patients after 2011.

\section{Estimate of Farmácia Popular program sustainability}

Based on the varying prevalence estimates in national surveys, the percentage of total $\mathrm{MoH}$ expenditures on medicines that would be required to treat all patients under the free medicines policy would vary from 4.9 to $18.7 \%$ for DM, and from 23.1 to $72.1 \%$ for HTN patients, respectively (Table 3 ).

\section{Discussion}

In this paper, we used secondary data from the FP program and data from several national surveys to estimate utilization, government expenditures, and patient out of pocket payments, for DM and HTN treatment and then consider these results in the context of FP sustainability.
This unique combination of information is not common in low- and middle-income countries.

The FP program co-exists with the free-of-charge medicines supply system in public health facilities, both of which are governmental mechanisms to provide medicines to patients with chronic illness. We studied antihypertension and hypoglycemic treatment, available free-of-charge in both programs, in order to understand FP program costs and sustainability.

For both diseases, the interventions were associated with similar patterns of change for the outcomes analyzed. The reduction in reference prices in 2009, together with administrative changes (AFP-II), resulted in an increase in patient cost sharing and associated drop out of users. The SNP, on the other hand, resulted in the opposite effects on these measures.

Affordability, as measured by level of patient out-ofpocket payment, decreased after AFP-II but improved substantially when medicines were dispensed for free following the SNP policy. Considering that, prior to the FP program, patients paid the full price of medicines outof-pocket at retail pharmacies, the simple existence of a government subsidy mechanism increased overall 


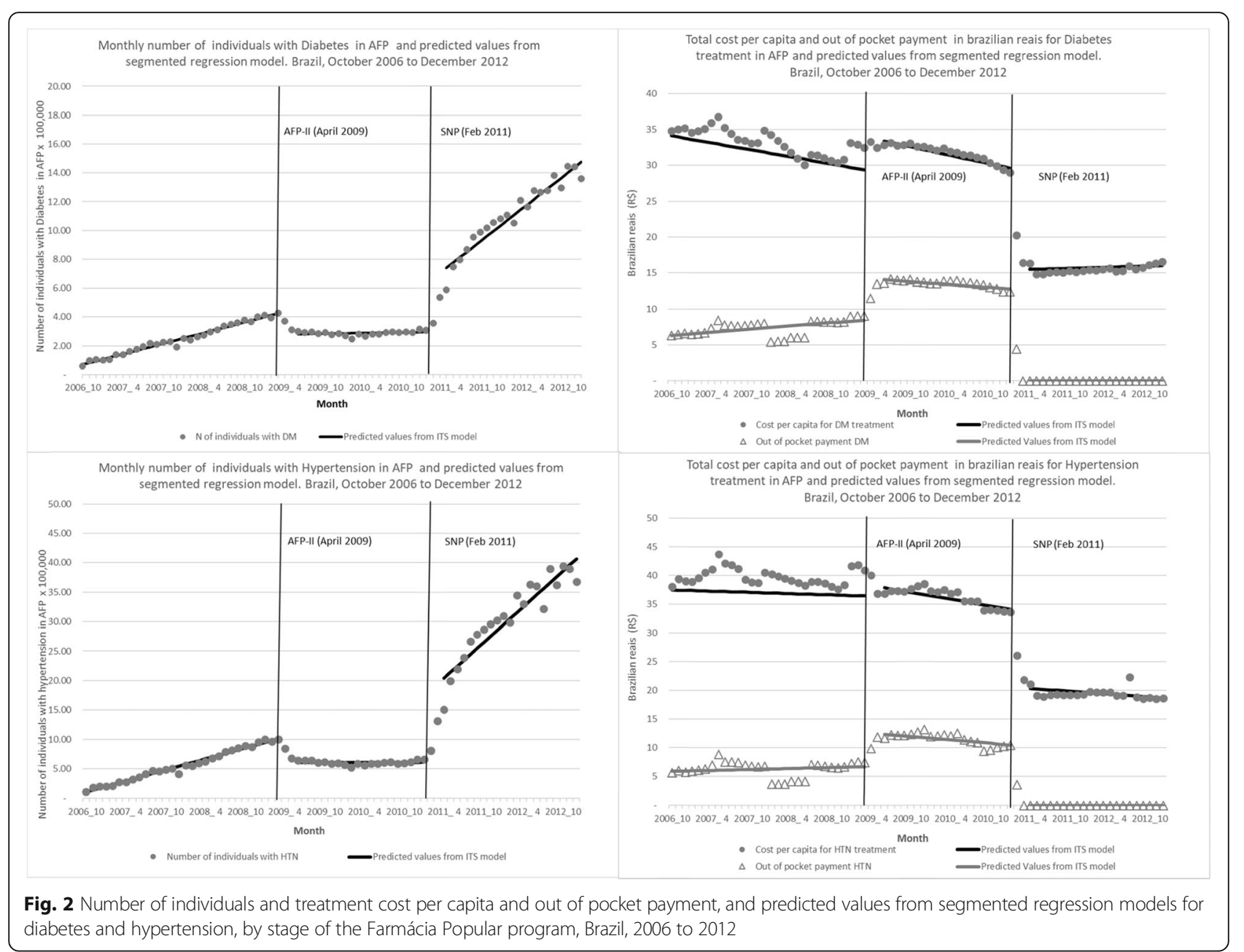

affordability over time. This is important since it has been shown that there is a high burden of medicines expenditures at household level in Brazil [10], despite freeof-charge medicines dispensing in SUS. Since private pharmacies are much more widespread than government health facilities and open for longer hours, this represented an improvement for patients in both affordability and convenience.

The effects of the reduction of reference prices following the AFP-II policy change have already been discussed in other publications [23, 24]. More restrictive enforcement measures were implemented, aimed at reducing corruption [25] and improving control and audit mechanisms [23], but this may have impaired program use by patients, judging by reductions in the number of individuals using the program. Not surprisingly, the SNP free medicines policy had the opposite effect, increasingly attracting users to FP.

Overall, the policy changes under AFP-II showed deleterious effects from both the government and patient perspectives. Despite reducing $\mathrm{MoH}$ overall expenditures by reducing their level of cost sharing, the savings were proportional to the number of individuals still using the program. There were no changes in efficiency, since there were no significant reductions in expenditure per treatment. After implementation of the free medicines SNP policy, overall $\mathrm{MoH}$ expenditures increased significantly because of increased coverage. However, the cost per treatment was about $40 \%$ more efficient, so the relative change in expenditures after 1 year of SNP was $700 \%$, despite a $1600 \%$ increase in the number of individuals treated. This improvement in efficiency may be related to gains from economies of scale in drug purchasing and substitution of generic drugs [26]. We previously found a growth of $20 \%$ in generic antihypertensive medicines use after SNP [27] as well as evidence of a $75 \%$ growth in sales volume for DM and HTN medicines covered in FP 2011 and 2012 [6].

We found large discrepancies in estimates of the size of the DM and HTN populations and FP coverage in the literature $[14,15,28-30]$, so we estimated coverage using two different methods. Our estimates for coverage of number of unique patients align with PMAQ, PNAUM, VIGITEL, while PNS is similar to our 
Table 3 Annual coverage and sustainability estimated for Farmácia Popular Program, (FP, PMAQ, PNAUM,VIGITEL,PNS), Brazil 2007 to 2015

\begin{tabular}{|c|c|c|c|c|c|c|c|c|c|c|c|c|c|c|}
\hline \multirow[t]{2}{*}{ Year } & \multirow[t]{2}{*}{ Prevalence $^{a}$} & \multicolumn{6}{|c|}{ Coverage (\%) } & \multirow{2}{*}{$\begin{array}{l}\text { Total MoH } \\
\text { expenditures } \\
\text { on medicines } \\
\text { (in Millions of } \\
\text { reais) }\end{array}$} & \multicolumn{6}{|c|}{$\begin{array}{l}\text { Estimated Expenditure to cover all people by Farmácia } \\
\text { Popular (as a percentage of total } \mathrm{MoH} \text { expenditures on } \\
\text { medicines) }\end{array}$} \\
\hline & & $\begin{array}{l}\overline{\mathrm{FP}} \\
\mathrm{Cov}_{-} 1^{\mathrm{b}}\end{array}$ & $\begin{array}{l}\mathrm{FP} \\
\mathrm{Cov}_{-} 2^{\mathrm{c}}\end{array}$ & $\mathrm{PMAQ}^{\mathrm{d}}$ & PNAUM ${ }^{e}$ & VIGITEL $L^{f}$ & $\mathrm{PNS}^{\mathrm{g}}$ & & $\begin{array}{l}\text { FP_- } \\
\text { Cov_1 }\end{array}$ & $\begin{array}{l}\text { FP_- } \\
\text { Cov_2 }\end{array}$ & PMAQ & PNAUM & VIGITEL & PNS \\
\hline \multicolumn{15}{|l|}{ Diabetes } \\
\hline 2007 & 9.3 & 11.2 & 2.3 & - & - & - & - & 5176.04 & 9.3 & 46.1 & - & - & - & - \\
\hline 2008 & 10.3 & 16.7 & 3.7 & - & - & - & - & 5866.20 & 8.5 & 37.8 & - & - & - & - \\
\hline 2009 & 10.0 & 17.4 & 3.9 & - & - & - & - & 6765.46 & 8.5 & 38.0 & - & - & - & - \\
\hline 2010 & 10.4 & 12.9 & 3.2 & - & - & - & - & 6988.75 & 10.3 & 42.0 & - & - & - & - \\
\hline 2011 & 10.3 & 33.2 & 8.9 & - & - & 16.7 & - & 8348.67 & 4.9 & 18.5 & - & - & 9.8 & - \\
\hline 2012 & 11.7 & 40.6 & 13.0 & 16.2 & - & 23.1 & - & 9656.00 & 6.0 & 18.7 & 15.0 & - & 10.5 & - \\
\hline $2013^{i}$ & 10.9 & 52.9 & 21.2 & - & 18.3 & 24.8 & 57.4 & $11,467.11$ & 5.5 & 13.7 & - & 15.8 & 11.7 & 5.1 \\
\hline \multicolumn{15}{|c|}{ Hypertension } \\
\hline 2007 & 35.8 & 6.1 & 1.2 & - & - & - & - & 5176.04 & 42.2 & 205.0 & - & - & - & - \\
\hline 2008 & 38.4 & 9.7 & 2.4 & - & - & - & - & 5866.20 & 39.2 & 158.7 & - & - & - & - \\
\hline 2009 & 37.7 & 9.8 & 2.4 & - & - & - & - & 6765.46 & 40.7 & 168.8 & - & - & - & - \\
\hline 2010 & 36.8 & 7.1 & 1.9 & - & - & - & - & 6988.75 & 43.9 & 166.2 & - & - & - & - \\
\hline 2011 & 36.8 & 24.3 & 6.0 & - & - & 16.1 & - & 8348.67 & 23.1 & 94.0 & - & - & 37.9 & - \\
\hline 2012 & 36.8 & 32.6 & 11.5 & 15.3 & - & 22.8 & - & 9656.00 & 25.3 & 72.1 & 54.2 & - & 36.2 & - \\
\hline $2013^{i}$ & 36.5 & 39.2 & 15.1 & - & 16.0 & 20.9 & 35.9 & $11,467.11$ & 25.1 & 65.2 & - & 61.5 & 47.0 & 27.4 \\
\hline
\end{tabular}

a. prevalence in the population 35 years old and older. VIGITEL (Brazilian Basic Indicators - http://tabnet.datasus.gov.br/cgi/idb2012/matriz.htm)

${ }^{\mathrm{b}}$ Coverage 1. Estimated coverage in FP - Numerator is the number of individuals with at least one dispensing within the year (individuals do not repeat)

${ }^{c}$ Coverage 2. Estimated coverage in FP Numerator is the average monthly individuals in each year (sum of individuals in each month within 1 year divided by 12 months) (the same individual can be count in different months in the same year)

${ }^{d} P M A Q=$ National Program for Improving Access and Quality of Primary Health Care (PMAQ); source: http://dab.saude.gov.br/portaldab/ape_pmaq.php

ePNAUM = Brazilian Survey on Medicine Access, Utilization and Rational Use of Medicines. Source: (Brasil. Ministério da Saúde. Secretaria de Ciência, Tecnologia e Insumos Estratégicos em Saúde. Departamento de Assistência Farmacêutica e Insumos Estratégicos et al., In press)

fVIGITEL = Surveillance of risk-factor for chronic diseases through telephone interviews; Source (Brasil. Ministério da Saúde. Secretaria de Vigilância em Saúde.

Secretaria de Ciência, Tecnologia e Insumos Estratégicos, 2015)

gPNS = National Health Survey; Source: (Sarmento Costa et al., 2016)

${ }^{h}$ Ministry of Health - national accounts (Rondineli et al., 2016)

i2013 AFP coverage is estimated based on coverage linear regression after February 2011

estimates of average number of monthly patients covered. If we assume that all DM and HTN patients would choose to obtain their medicines through FP private pharmacies, the program would consume in 2013 from 30.6 to $79 \%$ of the total $\mathrm{MoH}$ medicines budget for treating those two diseases alone. In the same year, the total estimated spending for primary health care medicines provided free-of-charge in public health facilities was $\mathrm{R} \$ 2.26$ billion [31]. As argued previously [6], since private pharmacies are reimbursed according to prescriptions filled and either public or private sector prescriptions are accepted, this poses important concerns regarding FP sustainability.

Considering the estimated financial outlay that would be required for $\mathrm{MoH}$ to cover all HTN and DM patients in the country through FP, it is likely that the program is sustainable only as a complementary policy and not as a substitute to distribution of medicines by the SUS. This is in accordance with the program's original purpose, which was to cover those low-income individuals with key chronic illnesses who used private health care services but could not afford medicines. However, due largely to deficiencies in the SUS, the FP came to be used as a substitute channel for provision of medicines [6]. Despite its positive impact on access, utilization, and affordability, it is important to consider financial sustainability when assessing the value of different medicines provision mechanisms in the country.

The study limitations include having no data on medicines that are not part of the FP, making it impossible to evaluate the impact of FP policies on the utilization of other medicines used to treat diabetes and hypertension. Furthermore, since we use data from surveys to estimate program coverage, we need to also consider the limitations of these sources of secondary data. 


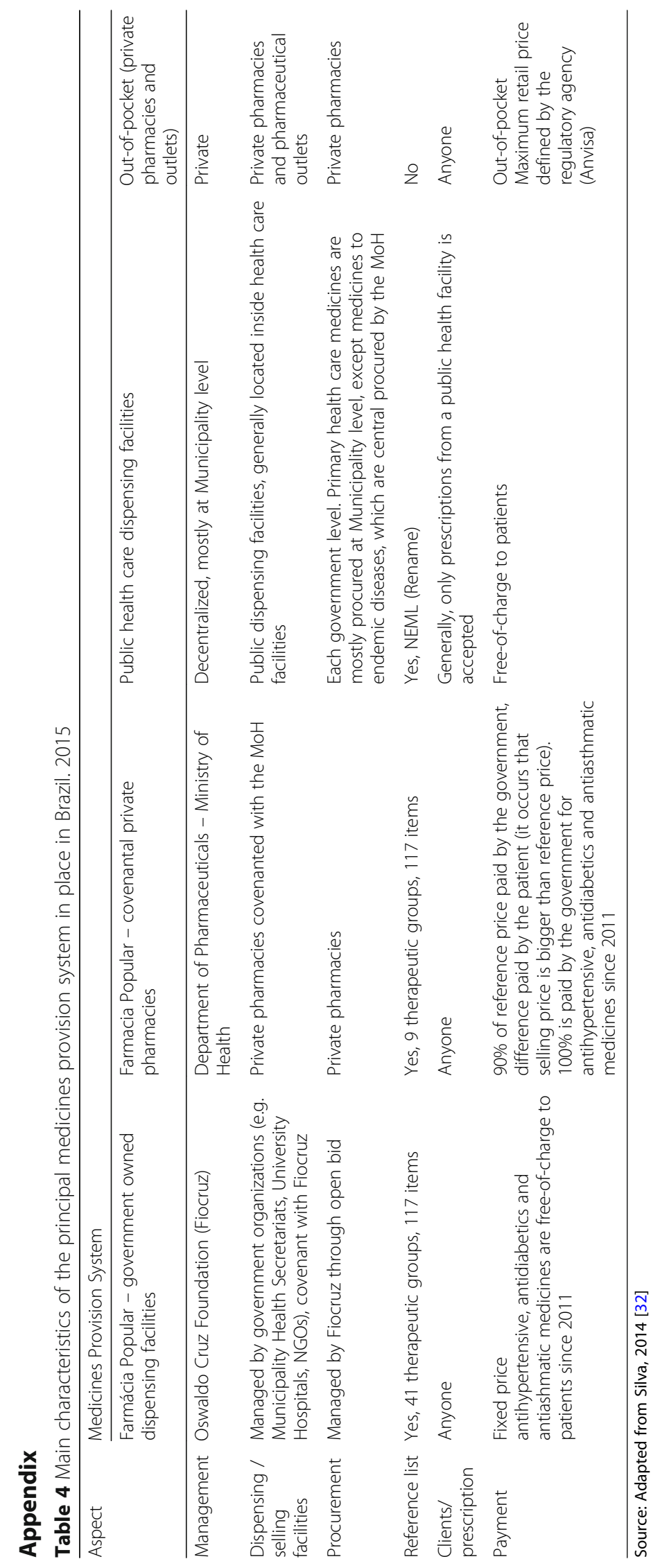


Individuals are allowed to be in multiple treatments. Per-capita cost was considered the total cost of all medicines covered in the month divided by the number of individuals in treatment under FP. As we used data at individual level, we think this is a reasonable approach, assuming that the distribution of medicines users would be similar in SUS and FP.

Despite increased investment over time in SUS strengthening, there was not any specific new policy or intervention change that occurred at the same point in time of the studied interventions $[6,12]$. Therefore, since we controlled for pre-existing trend and the small autocorrelation addressed in the analysis, we can infer that the observed changes estimated in this paper are related to the interventions and not to another confounding policy.

\section{Conclusion}

The FP greatly increased its coverage during the period analyzed and substantially improved the affordability of chronic illness treatment when medicines for diabetes and hypertension became free-of-charge in 2011. There was also an improvement in government expenditure efficiency, since the treatment cost per capita declined after 2011 due to purchasing leverage. However, overall $\mathrm{MoH}$ expenditures in the FP program increased substantially because of the increased number of users. FP appears to be sustainable only as a complementary policy, not as replacement for the SUS provision of medicines at primary healthcare facilities. Considering the magnitude of the FP program in the Brazilian pharmaceutical market, future studies should address the optimum treatment cost per capita, especially in the context of the Brazilian economic and political crises.

\section{Supplementary information}

Supplementary information accompanies this paper at https://doi.org/10. 1186/s12889-019-8095-0.

Additional file 1. Analysis Syntax - Diabetes and Hypertension

interrupted time series models.

Additional file 2. Diabetes and Hypertension interrupted time series models - original, analyzed data and graphs.

\section{Abbreviations}

AFP: Aqui tem Farmácia Popular- "Farmácia Popular" is available here: DM: Diabetes Melitus; FP: Farmácia Popular; HTN: Hypertension; MoH: Ministry of Health; SNP: Saúde não tem preço - SNP -Health has no price; WHO ERC: World Health Organization

\section{Acknowledgements}

The authors thank the Ministry of Health in Brazil for providing the data used in this study.

\section{Authors' contributions}

Author contributions: All authors made substantial contribution to study conception, ICME MRC, DRD made substantial contribution to study design. ICME, VLL, MRC, LAC, ADB and RMS were responsible for data acquisition. ICME, MRC and DRD were responsible for data analysis. All authors contributed to interpretation of data. ICME drafted the article and is guarantor. All authors provided critical revisions for important intellectual content and approved the final version.

\section{Funding}

Research grant from the World Health Organization Alliance for Health Policy and Systems. Dr. Ross-Degnan was supported in part by the National Institute of Diabetes And Digestive And Kidney Diseases of the National Institutes of Health under Award Number P30DK092924.

\section{Availability of data and materials}

The raw data is not available in the manuscript since the main database used is protected and not open access. However, the datasets used and/or analyzed during the current study [and its supplementary information files] are available from the corresponding author on reasonable request.

\section{Ethics approval and consent to participate}

The Brazilian National Ethics Committee (CONEP), by the National School of Public Health (ENSP) - Fiocruz - Brazil and the WHO ERC, approved the ISAUM-Br project, which is the base for this paper. The protocol numbers were respectively 294.585 no 438.743 and RPC554.

\section{Consent for publication}

Not applicable.

\section{Competing interests}

The authors declare that they have no competing interests.

\section{Author details}

${ }^{1}$ Division of Thoracic Surgery - Department of Surgery, University of Massachusetts Medical School, 67 Belmont street, Worcester, MA 01605, USA.

${ }^{2}$ Pharmaceutical Policy Research Fellowship, Department of Population Medicine, Harvard Medical School \& Harvard Pilgrim Health Care Institute, Landmark Center, 401 Park Drive Suite 401, Boston, MA 02215, USA. ${ }^{3}$ Department of Social Sciences, Sergio Arouca National School of Public Health, Oswaldo Cruz Foundation, 1480 Rua Leopoldo Bulhões \#905, Manguinhos, Rio de Janeiro 21041-210, Brazil. ${ }^{4}$ Department of Medicines and Pharmaceutical Services Policies, Sergio Arouca National School of Public Health, Oswaldo Cruz Foundation, 1480 Rua Leopoldo Bulhões \#624, Manguinhos, Rio de Janeiro 21041-210, Brazil. ${ }^{5}$ Phamacy Department, Federal University of Rio de Janeiro, Macaé Campus. Av. Aluizio da Silva Gomes, \#50, Granja dos Cavaleiros, Macaé 27930-560, Brazil. ${ }^{6}$ Postgraduate Program in Epidemiology, Federal University of Pelotas, Rua Marechal Deodoro 1160, Pelotas 96020-220, Brazil. ${ }^{7}$ Department of Population Medicine, Harvard Medical School \& Harvard Pilgrim Health Care Institute, Landmark Center, 401 Park Drive Suite 401, Boston, MA 02215, USA.

Received: 22 January 2019 Accepted: 17 December 2019

Published online: 08 January 2020

\section{References}

1. Marques AP, Montilla DER. Almeida W da S de, Andrade CLT de. Hospitalization of older adults due to ambulatory care sensitive conditions. Rev Saude Publica. 2014;48:817-26.

2. Brasil. Constituição da República Federativa do Brasil (Constitution of the Federative Republic of Brazil). 1988. http://www.planalto.gov.br/ccivil_03/ constituicao/constituicao.htm. Accessed 22 Oct 2012

3. Emmerick ICM, do Nascimento JM, Pereira MA, Luiza VL, Ross-Degnan D, ISAUM-Br Collaborative Group. Farmacia Popular Program: changes in geographic accessibility of medicines during ten years of a medicine subsidy policy in Brazil. Journal of Pharmaceutical Policy and Practice. 2015; 8. https://doi.org/10.1186/s40545-015-0030-x.

4. de Almeida ATC, Vieira FS, de Sá EB. Os efeitos do acesso a medicamentos por meio do Programa Farmácia Popular sobre a saúde de portadores de doenças crônicas não transmissíveis. In: CMAP 2016 a 2018 Estudos e Propostas do Comitê de Monitoramento e Avaliação de Políticas Públicas Federais; 2018. p. 28

5. Emmerick ICM, Campos MR, Luiza VL, Chaves LA, Bertoldi AD, Ross-Degnan $D$. Retrospective interrupted time series examining hypertension and diabetes medicines usage following changes in patient cost sharing in the 'Farmácia popular' programme in Brazil. BMJ Open. 2017;7:1-9. 
6. Luiza VL, Chaves LA, Campos MR, Bertoldi AD, Silva RM, Bigdeli M, et al. Applying a health system perspective to the evolving Farmácia Popular medicines access programme in Brazil. BMJ Glob Health. 2018;2(uppl 3): e000547.

7. da Silva RM, Chaves GC, Chaves LA, Campos MR, Luiza VL, Bertoldi AD, et al. Farmácia popular program: pharmaceutical market analysis of antihypertensive acting on the renin-angiotensin system medicines. Ciência \&amp. Saúde Coletiva. 2017;22:2501-12.

8. da Silva RM, Caetano R. Costs of public Pharmaceutical Services in Rio de Janeiro compared to Farmácia popular program. Rev Saude Publica. 2016 50. https://doi.org/10.1590/s1518-8787.2016050006605.

9. Garcia MM. Guerra Júnior AA, Acúrcio F de A. Avaliação econômica dos Programas Rede Farmácia de Minas do SUS versus Farmácia Popular do Brasil. Ciência \& Saúde Coletiva. 2017;22:221-33.

10. Instituto Brasileiro de Geografia e Estatística, editor. Conta-satélite de saúde: Brasil, 2010-2015. Rio de Janeiro: IBGE; 2017.

11. Fundação Getúlio Vargas. Expectativa dos consumidores para a inflação se mantém estável. 2018. https://portal.fgv.br/noticias/expectativaconsumidores-inflacao-se-mantem-estavel. Accessed 16 Apr 2019.

12. IPEA. Ipeadata. IPEA Data. 2019. http://ipeadata.gov.br/exibeserie.aspx?serid= 38389. Accessed 23 Apr 2019.

13. Brasil. Ministério da Saúde. Secretaria de Ciência, Tecnologia e Insumos Estratégicos. Componente populacional: resultados. Ministério da Saude; 2016.

14. Brasil. Ministério da Saúde. Secretaria de Vigilância em Saúde. Secretaria de Ciência, Tecnologia e Insumos Estratégicos. Vigitel Brasil : vigilância de fatores de risco e proteção para doenças crônicas por inquérito telefônico : estimativas sobre frequência e distribuição sociodemográfica do uso e fontes de obtenção dos medicamentos para tratamento da hipertensão e diabetes nas capitais dos 26 estados brasileiros e no Distrito Federal, 2011 a 2013. Brasília - DF: Ministério da Saúde; 2015

15. Brasil, Ministério da Saúde. Programa Nacional de Melhoria do Acesso e da Qualidade da Atenção Básica (PMAQ). Portal do Departamento de Atenção Básica. 2013. http://dab.saude.gov.br/portaldab/ape_pmaq.php. Accessed 27 Dec 2018

16. Instituto Brasileiro de Geografia e Estatística, editor. Pesquisa nacional de saúde, 2013: acesso e utilização dos serviços de saúde, acidentes e violências: Brasil, grandes regiões e unidades da Federação. Rio de Janeiro: Instituto Brasileiro de Geografia e Estatística-IBGE; 2015.

17. Wagner AK, Soumerai SB, Zhang F, Ross-Degnan D. Segmented regression analysis of interrupted time series studies in medication use research. J Clin Pharm Ther. 2002;27:299-309.

18. Linden A. Conducting interrupted time-series analysis for single- and multiple-group comparisons. Stata J. 2015;15:480-500.

19. Zhang F, Wagner AK, Soumerai SB, Ross-Degnan D. Methods for estimating confidence intervals in interrupted time series analyses of health interventions. J Clin Epidemiol. 2009;62:143-8.

20. Zhang F, Wagner AK, Ross-Degnan D. Simulation-based power calculation for designing interrupted time series analyses of health policy interventions. J Clin Epidemiol. 2011;64:1252-61.

21. Fretheim A, Zhang F, Ross-Degnan D, Oxman AD, Cheyne H, Foy R, et al. A reanalysis of cluster randomized trials showed interrupted time-series studies were valuable in health system evaluation. J Clin Epidemiol. 2015;68:324-33.

22. Fretheim A, Soumerai SB, Zhang F, Oxman AD, Ross-Degnan D. Interrupted time-series analysis yielded an effect estimate concordant with the clusterrandomized controlled trial result. J Clin Epidemiol. 2013;66:883-7.

23. da Silva RM, Caetano R, da Silva RM, Caetano R. "Farmácia popular do Brasil" program: characterization and evolution between 2004 and 2012. Ciência \&amp. Saúde Coletiva. 2015;20:2943-56.

24. Pinto CDBS, Miranda ES, Emmerick ICM, Costa ND, de CGSO C. Preços e disponibilidade de medicamentos no Programa Farmácia Popular do Brasil. Rev Saude Publica. 2010;44:611-9.

25. Brasil, Ministério da Saúde. Portaria No 3.089, de 16 de dezembro de 2009. Dispõe sobre a expansão do Programa Farmácia Popular do Brasil - Aqui Tem Farmácia Popular 2009.

26. Chama Borges Luz T, Garcia Serpa Osorio-de-Castro C, Magarinos-Torres R, Wettermark B. Trends in medicines procurement by the Brazilian federal government from 2006 to 2013. PLoS One. 2017;12:e0174616.

27. Emmerick ICM, Luiza VL, Campos MR, Ross-Degnan D, Chaves LA, Bertoldi AD, et al. Impact of consecutive subsidies policies on access to and use of medicines in Brazil - ISAUM-Br Final Report. Fundação Oswaldo Cruz; 2016. http://www6.ensp.fiocruz. br/repositorio/resource/369868. Accessed 21 Aug 2017.
28. Brasil. Ministério da Saúde. Secretaria de Ciência, Tecnologia e Insumos Estratégicos. Componente populacional : resultados / Ministério da Saúde, Secretaria de Ciência, Tecnologia e Insumos Estratégicos. - Brasília: Ministério da Saúde, 2016. 52 p. : il. - (Série Pnaum - Pesquisa Nacional sobre Acesso, Utilização e Promoção do Uso Racional de Medicamentos no Brasil; Caderno 3). ISBN 978-85-334-2375-6. http://bvsms.saude.gov.br/bvs/ publicacoes/componente_populacional_resultados_pnaum_caderno3.pdf.

29. RIPSA. Rede Interagencial de Informações para a Saúde. Brasil: Indicadores e Dados Básicos; 2012. http://tabnet.datasus.gov.br/cgi/idb2012/matriz.htm. Accessed 27 Dec 2018

30. Sarmento Costa K. Urruth Leão Tavares N, Serrate Menque S, Aurélio Pereira M, Carvalho Malta D, Barbosa da Silva Júnior J. Obtenção de medicamentos para hipertensão e diabetes no Programa Farmácia Popular do Brasil: resultados da Pesquisa Nacional de Saúde, 2013. Epidemiologia e Serviços de Saúde. 2016:25:10-1.

31. Vieira FS. Evolução do gasto com medicamentos do Sistema Único de Saúde no período de 2010 a 2016. 2018. http://www.ipea.gov.br/portal/ images/stories/PDFs/TDs/180117_td_2356.pdf.

32. Silva RM da. Programa "Aqui tem Farmácia Popular": expansão entre 20062012 e comparação com os custos da assistência farmacêutica na Secretaria Municipal de Saúde do Rio de Janeiro Rio de Janeiro [Program Here There Is Farmacia Popular: expansion between 2006-2012 and cost comparison with pharmaceutical services in Rio de Janeiro Municipality Health Secretariat]. Tese. Universidade do Estado do Rio de Janeiro; 2014.

\section{Publisher's Note}

Springer Nature remains neutral with regard to jurisdictional claims in published maps and institutional affiliations.

Ready to submit your research? Choose BMC and benefit from

- fast, convenient online submission

- thorough peer review by experienced researchers in your field

- rapid publication on acceptance

- support for research data, including large and complex data types

- gold Open Access which fosters wider collaboration and increased citations

- maximum visibility for your research: over $100 \mathrm{M}$ website views per year

At $\mathrm{BMC}$, research is always in progress.

Learn more biomedcentral.com/submissions 